\title{
Self-integrity as the Protective Shield for Peer Group Loitering among At-risk Youth
}

\author{
Sheau Tsuey Chong ${ }^{1}$, Juliana Rosmidah Jaafar ${ }^{2}$, Samsudin A. Rahim ${ }^{1}$, Nor Ba'yah Abdul Kadir ${ }^{1}$, Subhi, N. ${ }^{1}$, \\ Denise $\mathrm{Koh}^{3}$, Lina Liyana Khairuddin ${ }^{2} \&$ Nen, S. $^{2}$ \\ ${ }^{1}$ Centre for Youth Empowerment, Universiti Kebangsaan Malaysia, Bangi, Malaysia \\ ${ }^{2}$ School of Psychology and Human Development, Faculty of Social Sciences and Humanities, Universiti \\ Kebangsaan Malaysia, Bangi, Malaysia \\ ${ }^{3}$ School of Educational Methodology and Practices, Faculty of Education, Universiti Kebangsaan Malaysua, \\ Bangi, Malaysia \\ Correspondence: Sheau Tsuey Chong, Centre for Youth Empowerment, Universiti Kebangsaan Malaysia, 43600 \\ UKM Bangi, Selangor, Malaysia. Tel: 60-3-8921-4847. E-mail: stchong@ukm.my
}

Received: June 4, 2012 Accepted: June 16, $2012 \quad$ Published: July 16, 2012

doi:10.5539/ass.v8n9p98 URL: http://dx.doi.org/10.5539/ass.v8n9p98

\begin{abstract}
Loitering among urban youth is often linked with group activities that occur in public places without having any specific purposes. The activity is conducted together as a group among those who share the same values and ideologies. This article analyzes the involvement of prosocial and antisocial activities among 636 young people (423 loiterers and 213 non-loiterers), aged 13 to 25 years in at-risk areas in Kuala Lumpur. The purpose of this study is to compare the prosocial and antisocial behavior of at-risk young people premised by loitering and non-loitering behavior. The researchers compared loiterers and non-loiterers in terms of their levels of self-integrity that may contribute to prosocial and antisocial behaviors. The results showed that at-risk young people who had high levels of self-integrity had lower risk of getting involved in group loitering. On the other hand, the results also indicated that group loitering behavior led to antisocial behavior. In addition, there was no significant difference between loitering and non-loitering behavior in terms of the level of participation in prosocial community activities. This finding supports previous loitering literature which suggests that loitering behavior among young people will lead to risky behaviors. In order to prevent more at-risk young people getting involved in group loitering which may subsequently lead to antisocial behavior, positive youth development programs should focus on boosting young people's self-integrity. Future studies could focus on the effect of loitering behavior in other at-risk setting in rural area.
\end{abstract}

Keywords: loitering, adolescent, prosocial behavior, antisocial behavior

\section{Introduction}

Loitering behavior among young people is not only a concern to the society, it may also lead to anti-social behaviors. Loitering behavior is defined as gathering of a group of people at public places, with no specific purposes (Samsudin, 1995). Scenes of groups of young people loitering in their urban neighbourhoods is worrying because previous research suggest that loitering is associated with delinquent behaviors and criminal activities (Miles and Okamoto, 2008; Andershed et. al, 2001). This is especially true for young people who reside in urban neighbourhoods which have been identified as having high occurrence of loitering. In this paper, young people from neighbourhoods that have high occurrence of loitering are referred to as at-risk young people. Characteristics of at-risk young people are those who lack: (1) family support, (2) parental supervision, (3) social skills, (4) aspiration, self-esteem and emotional control, (5) appropriate role model, and (6) positive peer influence (Samsudin, 2009). In addition, Samsudin also asserts that young people who grow up in low income family and in unsatisfactory living condition are also considered as at-risk young people. Lower socioeconomic status, unsafe residency and unstructured community organisations are among the factors that put youths at a high risk area to more likely be exposed to all kinds of negative behaviors and crimes (Daniel et al., 2009). This paper examines antisocial behavior among young people who have been identified as at-risk young people. 
The literature is heavily tilted to the negative side of loitering and build the stereotype that young people from at-risk areas are trouble-makers (Kamans et. al, 2009). Areas with high "trouble-makers" create an unsafe neighbourhood, and thus, produce more trouble-makers. This vicious cycle would keep on rolling until some preventive measures are taken to overcome this problem. On the other hand, the researchers would challenge the idea that social capital (trust and reciprocity among group members), might promote prosocial behaviors (Putnam, 1993). Prosocial behaviors are behaviors that are performed to others which imposed positive impact on individuals or groups. For example, involvement in community activities, whether voluntary or through external influences is prosocial behavior and it has a significant impact in the neighbourhood community. The positive effect of social capital could be seen through active participation in community because individuals are able to share values, becoming more understanding, have more tolerance and are more open to career opportunities (Granovetter, 1973).

The discussion so far points to the conclusion that social network among youth including loiterers could lead to both antisocial and prosocial behaviors. The hypothesis of this study is that self-integrity may be a protective factor against antisocial behaviors even among youths who loiter. Chong et al. (2011b) found that self-integrity was the internal factor which contributes to the levels of resilience among urban at-risk young people. High levels of resilience could help young people in facing challenging life experiences and build adaptive skills in enhancing personal protective factors (Chong et al., 2011b).

This paper proposes that when a group of individuals hang out together, members of the group would build a trustworthy relationship with each other and enhance their friendship social capital (Chong et al., 2011a). This social capital may improve young peoples' well being and general safety in a particular neighbourhood, as they share the same responsibility and expectations (Chong, 2010). This study aims to compare the prosocial and antisocial behavior based on loitering behavior and non-loitering behavior among at-risk young people. In addition, the levels of self-integrity was also compared among loitering group and non-loitering group.

\section{Materials and Method}

\subsection{Respondents}

A convenience sampling consisting of 744 young people aged between 13 to 25 years (mean $=17.85$ ), who live in an identified at risk area in Kuala Lumpur, were recruited to join this study. Data were obtained via self-administered questionnaire. Data collection was conducted between February and December 2010. From the 744 youth recruited, only individuals who answered loitering (with friends) and did not loiter (with friends) were selected for further analysis in this study. Hence, 636 sets of data were used (which consisted of 423 loiterers and 213 non-loiterers). Of the 636 respondents, $52.9 \%$ were males and $46.9 \%$ were females. Respondents were categorised into Malays (87.1\%) and non-Malays (12.9\%). In general, the majority of residents $(62.1 \%)$ in this area were categorised as having low income (with monthly household earnings that ranged between RM50 to RM4,600 (Mean = RM1116.05). This situation is further compounded as they are living in the metropolitan area of Kuala Lumpur.

\subsection{Research Instruments}

Prosocial behavior, antisocial behavior and self-integrity were measured using the 23 Developmental Assets Questionnaire (DAQ-23) (Abdul Kadir et al., in press). The DAQ-23 consists of 23 positive internal and external assets that are referred to as the "positive experiences of the self and others among youth". The reliability of these items in our population is acceptable, with Cronbach alpha in each item ranging from 0.87 to 0.88 .

Prosocial behavior. Ten items from the DAQ-23 were used to measure prosocial behavior (see Appendix A). Frequency of participation in group activities in the past six months were recorded. These activities included involvement in uniformed bodies (i.e. Red Crescent Society, Girl Guides, Scout), communal work, religious activities, planning in youth activities and gotong-royong (Note 1). All items were measured using a six-point Likert scale, $1=$ Never to $5=$ More than 6 times.

Antisocial behavior. Eighteen items consisting of a list of antisocial behaviors in the DAQ-23 were used to measure antisocial behavior. The respondents were asked to declare whether they were involved in these behaviors in the past six months from the point of data collection was conducted. The list of antisocial behaviors including smoking, truancy, drug use and alcohol consumption.

Self-Integrity. Data on self-integrity were collected using five items from the DAQ-23. A five point Likert scale ranging from $1=$ Strongly disagree to $5=$ Strongly agree was used in these items. Respondents were asked to indicate the levels of self-worth, for example, to what extent they have no problem if people don't like them. 


\section{Results and Discussion}

This study found that $66.5 \%$ of the respondents $(n=423)$ were engaged in group loitering. The finding is presented in three sections, i) involvement in prosocial behavior, ii) involvement in antisocial behavior and iii) self-integrity and group loitering.

\subsection{Involvement in Prosocial Behavior}

T-test was used to identify the mean difference of conducting prosocial activities between young people who loitered and those who did not. Results in Table 1 showed that there were no significant differences found between Loitering Groups $(\mathrm{M}=30.85, \mathrm{SD}=12.10)$ and Non-Loitering Groups $(\mathrm{M}=31.52, \mathrm{SD}=13.18), \mathrm{t}(634)$ $=0.63, \mathrm{p}>0.05$. (see Table 1$)$

Table 1. Differences between loitering group and non-loitering groups in term of prosocial activities

\begin{tabular}{lllll}
\hline Variable & $\mathrm{M}$ & $\mathrm{SD}$ & $\mathrm{t}$ value & $\mathrm{p}$ \\
\hline Loitering Group & 30.85 & 12.10 & 0.63 & 0.53 \\
Non-Loitering & 31.52 & 13.18 & & \\
Group & & & & \\
\hline
\end{tabular}

This indicates that the trustworthy relationship among peers which was built through loitering did not contribute to prosocial behavior. In other words, there was no evidence to support the idea that building social capital from friendship networks could lead to prosocial behavior. Even though young people might be knitting strong social fabric with their peers, this social interaction did not result in greater cooperation in the community. Surprisingly, those young people who did not get involved in group loitering also did not seem to promote prosocial behavior in the community. Thus, this indicates that at-risk young people and their peer group relationship might not be a good indicator of levels of cooperation among community members.

\subsection{Involvement in Antisocial Behavior}

Table 2 revealed the t-test result showing that there was a significant difference between Loitering Group $(\mathrm{M}=$ $2.74, \mathrm{SD}=2.74)$ and Non-Loitering Group $(\mathrm{M}=0.48, \mathrm{SD}=1.12), \mathrm{t}(634)=11.55 \mathrm{p}<0.05$ with regards to their involvement in antisocial behavior. (see Table 2)

Table 2. Differences between loitering group and non-loitering groups in term of antisocial behaviour

\begin{tabular}{lllll}
\hline Variable & $\mathrm{M}$ & $\mathrm{SD}$ & $\mathrm{t}$ value & $\mathrm{p}$ \\
\hline Loitering Group & 2.74 & 2.74 & 11.55 & 0.00 \\
Non-Loitering & 0.48 & 1.12 & & \\
Group & & & & \\
\hline
\end{tabular}

Young people who loitered with their friends tended to commit mild misconduct behaviors or delinquency. The results of this study supported previous studies on the effect of loitering among at-risk young people (Andershed et al., 2001). This shows that young people who had built friendship network with their peers tended to use this networking to conduct misbehavior. In other words, if negative values were shared among the group members, it is possible that the idea of misconduct could spread and grow among friends. Past studies have demonstrated that young people who had committed minor offences in their young age may turn up committing serious and major crimes when they get older (Ma et al., 2002; Monahan et al., 2009). Previous studies suggested that members of a group with shared interest but did not have clear visions about their future tended to be involved in social problems such as bullying, mugging and robbing (Gatti et al., 2005; Dishion et al., 2005; Katz and Fox, 2010). Thus, at-risk young people might be involved in crimes when they become adults. Results of this study suggest that they might commit crimes with their friends. In other words, gang crimes might be part of the vicious cycle in producing the 'inbreed' adult offenders in at-risk neighbourhood of their origin. So, the inner strength, like self-integrity of young people in resisting the influence of their peer might be the protective factor from the misconduct in crime.

\subsection{Self-integrity among Loitering and Not-Loitering Groups}

Table 3 showed result from the t-test analysis that there was a significant difference between those who were in Loitering Group $(\mathrm{M}=22.84, \mathrm{SD}=3.97)$ and those who were in Non-loitering Group $(\mathrm{M}=23.91, \mathrm{SD}=4.15)$, $\mathrm{t}(634)=3.17 \mathrm{p}<0.05$. (see Table 3 ) 
Table 3. Differences between loitering group and non-loitering groups in term of self-integrity

\begin{tabular}{lllll}
\hline Variable & $\mathrm{M}$ & $\mathrm{SD}$ & $\mathrm{t}$ value & $\mathrm{p}$ \\
\hline Loitering Group & 22.84 & 3.97 & 3.17 & 0.02 \\
Non-Loitering & 23.91 & 4.15 & & \\
Group & & & & \\
\hline
\end{tabular}

This result showed that those who did not loiter with their friends had higher levels of self-integrity, as compared to their counterpart. In other words, good companionship might enhance greater levels of self-value in young people. Living in at-risk neighbourhood demands not only young people to be adaptive and self-resistant through daily challenges but also a good peer selection is crucial in preventing young people from getting involved in negative behavior. Those who have higher self-integrity, picture themselves as having higher self-worth (Stone et al., 2003). Thus, integrity could be an internal asset for those who lived in at-risk neighbourhood (Chong et al., 2011). Furthermore, those who achieved higher levels of self-integrity might be more independent and firm in resisting group loitering behavior. So, peer influence might have lesser effect on those who valued themselves highly.

\section{Conclusion}

The finding of this study analysed the positive and negative effects of loitering amongst 13 to 25 years age of respondents who lived in an at-risk area in Kuala Lumpur. Those effects were identified by respondents' involvement in prosocial or antisocial behavior. The findings indicated that youth as a group, whether they loiter or not might have potential to participate in communal activities. Results showed no evidence that those who involved with loitering showed no interest to engage in prosocial behavior vice versa. Thus, community development planners should focus on more beneficial activities for the at-risk young people. Results of this present research demonstrated that young people who loitered tended to be involved in antisocial behavior. Even though loitering might be perceived as an easy and harmless way to pass time, it might have negative effect on the neighbourhood safety. Also, school counsellors and school psychologists could help in exploring young people's reflection on self-integrity and then enhance their resiliency in combating group loitering behavior. Future studies could further explore loitering behavior on rural youth who are facing challenges in at-risk community.

\section{References}

Abdul Kadir, Nor Ba'yah., Samsudin Abdul Rahim, Mimi Hanida Abdul Talib, Wan Amizah Wan Mahmud, Nashrudin Subhi, ... Syarafunisa Ismail. (In Press). 23 Developmental Assets Questionnaire in a Malaysian Context: Development and factor structure. Under review journal paper.

Andershed, H., Kerr, M., \& Stattin, H. (2001). Bullying in school and violence on the streets: Are the same people involved? Journal of Scandinavian Studies in Criminology and Crime Prevention, 2, 31-49. http://dx.doi.org/10.1080/140438501317205538

Chong, S. T. (2010). Is family social capital the starting base of more social capital? Paper presented at Penjanaan Ilmu Serumpun ke Arah Kelestarian Penyelidikan dan Kecemerlangan Akademik, 3rd International Conference of Sebumi, Malaysia.

Chong, S. T., Rahim, S. A., Subhi, N., Kadir, N. B. A., Jusoff, K., Talib, M. H. A., ... Ismail, S. (2011a). Self-integrity and family support as assets for resilient urban at-risk young people. World Applied Sciences Journal, 12(Special Issues of Social and Psychological Sciences for Human Development), 20-24.

Chong, S. T., Farquharson, K. Er, A. C., Lukman, Z. M., \& Mostafa Kamal Mokhtar. (2011b). Enhancing youth civic engagement and generalized trust through bonding social capital among friends. Pertanika Journal of Social Sciences \& Humanities, 19(S), 57-64.

Daniel, J. Z., Hickman, M., Macleod, J., Wiles, N., Lingford-Hughes, A., Farrell, M., ... \& Lewis, G. (2009). Is socioeconomic status in early life associated with drug use? A systematic review of the evidence. Drug and Alcohol Review, 28(2), 142-153. http://dx.doi.org/10.1111/j.1465-3362.2008.00042.x

Dishion, T. J., Nelson, S. E., \& Yasui, M. (2005). Predicting early adolescent gang involvement from middle school adaptation. Journal of Clinical Child and Adolescent Psychology, 34(1), 62-73. http://dx.doi.org/10.1207/s15374424jccp3401_6 
Gatti, U., Tremblay, R. E.,Vitaro, F., \& McDuff, P. (2005). Youth gangs, delinquency and drug use: A test of the selection, facilitation, and enhancement hypotheses. Journal of Child Psychology and Psychiatry, 46(11), 1178-1190. http://dx.doi.org/10.1111/j.1469-7610.2005.00423.x

Granovetter, M. (1973). The strength of weak ties. American Journal of Sociology, 78(6), 1360-1380.

Kamans, E., Gordijn, E. H., Oldenhuis, H., \& Otten, S. (2009). What I think you see is what you get: Influence of prejudice on assimilation to negative meta-stereotypes among Dutch Moroccan teenagers. European Journal of Social Psychology, 39, 842-851. http://dx.doi.org/10.1002/ejsp.593

Katz, C. M., \& Fox, A. M. (2010). Risk and protective factors associated with gang-involved youth in Trinidad and Tobago. Rev Panam Salud Publica, 27(3).

Ma, H. K., Shek, D. T. L., Cheung, P. C., \& Tam, K. K. (2002). A longitudinal study of peer and teacher influences on prosocial and antisocial behavior of Hong Kong Chinese adolescent. Social Behavior and Personality, 30(2), 157-168.

Miles, B. W., \& Okamoto, S. K. (2008). The social construction of deviant behavior in homeless and runaway youth: Implications for practice. Child Adolescent Social Work Journal, 25, 425-411. http://dx.doi.org/10.1007/s10560-008-0131-3

Monahan, K. C., Steinberg, L., \& Cauffman, E. (2009). Affiliation with antisocial peers, susceptibility to peer influence, and antisocial behavior during the transition to adulthood. Developmental Psychology, 45(6), 1520-1530. http://dx.doi.org/10.1037/a0017417

Putnam, R. D. (1993). The prosperous community: Social capital and public life. American Prospect, 13, 35-42.

Samsudin, A. R. (1995). Tingkah laku lepak di kalangan remaja. Kuala Lumpur: Institut Penyelidikan Pembangunan Belia, Kementerian Belia dan Sukan Malaysia

Samsudin, A. R. (2009). Indeks Belia Malaysia. Kuala Lumpur: Institut Penyelidikan Pembangunan Belia, Kementerian Belia dan Sukan Malaysia

Stone, W., Gray, M., \& Hughes, J. (2003). Social capital at work: How family, friends and civic ties relate to labour market outcomes. Research Paper 31. Melbourne: Australian Institute of Family Studies.

Winayanti, L., \& Lang, H. C. (2004). Provision of urban services in an informal settlement: A case study of Kampung Penas Tanggul, Jakarta. Habitat International, 28, 41-65. http://dx.doi.org/10.1016/S0197-3975(02)00072-3

\section{Note}

Note 1. Gotong-royong is defined as a kind of helping behavior done by a group of people to attain a shared goal or mutual self-cooperation (Winayanti \& Lang, 2004). 